\section{Golden opportunities?}

UNIVERSITIES and research councils in Britain are waiting to hear what new arrangements the government has in mind for the commercial exploitation of publicly-funded research following its decision to remove the first refusal rights of the British Technology Group (BTG) on development of novel ideas arising from holders of research council grants and research council employees. Whatever happens, it is bound to give inventors and their employers much greater say than hitherto in how exploitation is to proceed, but will also bring increased responsibilities. Many universities will find their new rôle as entrepreneurs unfamiliar, and the government is now devising safeguards to ensure that potentially valuable results do not fall between several stools. Until the new arrangements are clear, BTG considers itself in business as usual.

The first problem is that of protection. Under the 1977 Patent Act almost any public disclosure of an invention (with the exception of international exhibitions) would invalidate a subsequent patent application. The National Research Development Corporation, now part of BTG, is generally agreed to have done a good job on this score, often managing to file applications only days or hours before publication. Many in the universities hope and expect BTG to continue that service, but BTG's present constitution does not allow it to offer a patenting service on a straightforward commercial basis.

A second area for concern is whether venture capital funds will be available for ideas, patentable or otherwise, at a sufficiently early stage. Venture capital funds, which offer long-term equity finance backed up by active management participation, have been thriving in Britain in recent years. According to Ms Susan Lloyd, editor of UK Venture Capital Journal, more than 45 independent funds have been established in Britain since 1980 even excluding funds managed by clearing banks and insurance companies. Several companies boast special expertise in new technologies - for example, Advent Ltd, Prutec Ltd and Thompson Clive Ltd. But most venture capital companies will want to see a prototype and a business plan before they invest, whereas BTG have been willing to invest in "a spot on a chromatogram".

If the risks of investment in new technology are high, so too are the potential rewards. Mr David Cooksey, managing director of Advent Ltd, says he looks for returns of 40 per cent compound interest per annum, but he has to be prepared to wait 5 to 10 years, or even longer: investors cannot expect annual dividends. This type of financing has been made possible by the creation in 1980 of the unlisted securities market, where shares in companies not meeting the strict requirements of the stock exchange can be traded. The government's New Business Expansion Scheme offers generous tax incentives to investors in growing businesses, and available funds seem likely to increase. The biggest problem is in matching up an academic inventor with suitable business expertise. In this respect Britain lags behind the United States where enlightened policies of the Massachusetts Institute of Technology and Stanford are widely held to have been responsible for Route 128 and Silicon Valley.

Another looming problem arises from the fact that while BTG held the purse strings, British inventors were routinely rewarded through their universities or research coun-

cils, often on a formula basis; without BTG individual stakes will be larger and there may be more arguments over ownership.

So what does a venture capitalist like Cooksey have to say to academic inventors? The academic aspiring to be an entrepreneur does not have to give up the university life altogether and he should be prepared to tout his wares to several companies before finding a partner. He may have a lot to gain, and should ensure that his host institution takes its responsibilities seriously, both in the facilities it provides to start-up companies and its investment policies. Some universities, including those at Oxford and Cambridge, have already made investments in venture capital companies; as government provision for universities decreases in real terms there will be pressure on many others to follow suit.

Tim Beardsley

\title{
Small-business research
}

\section{Innovation fund oversubscribed}

\section{Washington}

THE federal government has been inundated with proposals from small firms seeking research contracts under the Reagan Administration's controversial new law compelling 11 major agencies to spend more of their research money on companies with fewer than 500 employees.

The law, the Small Business Innovation Development Act, was approved by Congress last year over the vigorous objections of the universities, which complained that it would divert scarce federal funds from urgently needed basic research to applied research of dubious calibre. Since then, the Small Business Administration has been waiting anxiously to discover whether small businesses would be able to put forward enough good research ideas to justify spending the $\$ 40$ million available under the scheme this year.

To the undisguised relief of the administration, federal agencies partipating in the scheme have by now received some 9,000 proposals - more than enough, according to the Small Business Administration, to ensure that the 700 contracts awarded this year will be of high quality.

The act is being phased in over five years and the proportion of federal research funds set aside for small businesses is to be increased annually. Ultimately, it is to reach a level at which every federal agency with an extramural research and development budget of more than $\$ 100$ million will set aside 1.25 per cent of that budget for contracts with small firms. As a result, an estimated $\$ 1,400$ million of federal research money will be pumped into small companies.

This autumn's first round of contracts will be on a small scale, ranging from $\$ 30,000$ to $\$ 50,000$ and involving only a few months of work to investigate the technical feasibility of research proposals. The sponsoring agencies will face harder decisions in the second phase of the exercise, when it will have to decide which projects should be continued and enlarged within a ceiling of $\$ 500,000$.

However, controversy about the working of the act persists. Michigan Democrat John Dingell is sponsoring an

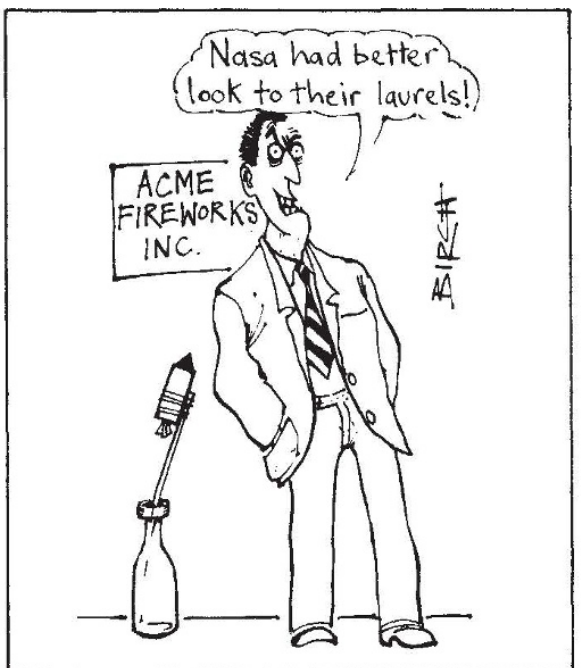

amendment in Congress that would prevent the National Institutes of Health (NIH), one of the agencies involved in the scheme, from supporting research proposals that would have failed under normal NIH procedures. Digell fears that the law will result in NIH funds being "raided" to support ideological objectives secondary to the institutes' biomedical research missions. An NIH spokesman conceded that the 598 proposals received under the scheme had achieved lower than average merit scores from NIH reviewers. But she said NIH intended to award its full quota of $\$ 6$ million for small business research this year.

Peter David 